\title{
PCR screening and allele frequency estimation of bovine leukocyte adhesion deficiency in Holstein and Gir cattle in Brazil
}

\author{
Luciana A. Ribeiro ${ }^{1}$,Erica E. Baron ${ }^{1}$, Mário L. Martinez ${ }^{2}$ and Luiz L. Coutinho ${ }^{l}$
}

\begin{abstract}
Bovine leukocyte adhesion deficiency (BLAD) is a disease known to affect the Holstein cattle breed throughout the world. Eighty-eight Holstein dairy cows and 88 Gir dairy bulls were genotyped by PCR for the CD18 BLAD alelle. The frequency of the BLAD mutant allele and the BLAD-carrier prevalence in Brazilian Holstein cows were 2.8 and 5.7\%, respectively. No mutant allele was found in any of the 88 Gir animals. We conclude that the CD18 gene mutation is prevalent in Brazilian Holstein cattle and absent or present at a very low frequency in Gir cattle.
\end{abstract}

\section{INTRODUCTION}

Bovine leukocyte adhesion deficiency (BLAD) is a recessive autosomal disease that is caused by a deficiency in leukocyte surface glycoproteins known as integrins. These proteins are responsible for the cell-cell interactions necessary for neutrophils to adhere to vascular endothelium, enter the tissues, and destroy invading pathogens (Kishimoto et al., 1987).

The integrin family includes leucocyte function-associated antigen (LFA-1), macrophage antigen (Mac-1) and p150,95. These three adhesion molecules are heterodimers, composed of a unique alpha subunit (CD11a, CD11b and CD11c, respectively) and a common beta subunit (CD18) (Springer, 1990). Since integrin expression requires intracellular association of both CD11 and CD18 subunits, CD18 defects prevent all integrin functions (Kishimoto $e t$ al., 1987).

Cattle affected by BLAD have severe and recurrent bacterial infections such as pneumonia, gingivitis, impaired pus formation, delayed wound healing, stunted growth and persistent, marked neutrophilia (Kehrli et al., 1990; Tajima et al., 1993; Nagahata et al., 1993; Gerardi, 1996). Blood samples analyzed 41 days after birth of suspect BLAD animals demonstrate progressive neutrophilia and excessive leukocytes (100,000 leukocytes/ $\mu$ l) (Kehrli et al., 1994).

The relatively low mutant allele frequency rate found in Holstein cattle, as well as low expression of specific clinical signs suggest that most calves with BLAD die before diagnosis, probably before one year of age. Some cows are able to survive for more than two years; however their reproductive and milk performances are poor (Garcia et al., 1996). Consequently, BLAD is an economically important disease, emphasizing the need for genetic screening for the elimination of the mutant allele from the population.
Two point mutations have been identified in the gene that encodes bovine CD18 in Holstein cattle affected with BLAD (Shuster et al., 1992). One mutation replaces adenine with guanine at nucleotide 383 , and the other replaces cytosine with thymine at nucleotide 775 . The latter is a silent mutation. It causes no alteration in the amino acid sequence; consequently, it has no phenotypic effect. The mutation at nucleotide 383 substitutes glycine for aspartic acid at amino acid 128. This mutation eliminates a TaqI restriction site and creates a HaeIII site, which allows the identification of normal, carrier and affected animals.

BLAD was first identified in Holstein-Friesian cattle at the beginning of the eighties (Gerardi, 1996), and no study has reported the occurrence and etiology of this disease in other breeds. The mutation found in the Holstein breed can be traced back to a heterozygote bull (Osborndale Ivanhoé), which due to its elevated genetic merit for milk production has been widely used in artificial insemination. This bull and its offspring (Penstate Ivanhow star - son and Carlin M Ivanhoe Bell - grandson) founded one of the main Holstein lineages. They are also responsible for spreading BLAD to several herds worldwide (Shuster et al., 1992).

The occurrence of BLAD-affected animals throughout the world is probably due to the practice of artificial insemination with carrier bull semen. In Brazil, Holstein animals, semen and embryos are imported for dairy cattle breeding. Furthermore, Brazilian producers cross Holstein cattle with Gir cattle without controlling for BLAD, and thus there is a possibility that this mutation can be transferred to the Gir breed.

The Gir breed is considered, either as a pure breed or in crosses, as an alternative to Holsteins for milk production in tropical areas. It is responsible for close to $25 \%$ of the registered milk production in Brazil, being surpassed only by the Holstein breed. A breeding program that has

${ }^{1}$ Departamento de Produção Animal ESALQ-USP, Av. Pádua Dias, Caixa Postal 9, 13418-900 Piracicaba, SP, Brasil. 
accompanied the development of Gir herds reports an average of $2,766 \mathrm{~kg}$ of milk/291 lactating days for 7,944 cows (Martinez et al., 1998). Nevertheless, calf mortality is still high, being $3 \%$ for animals under one year of age. Consequently, this study was conducted in order to determine the allelic frequency of the BLAD mutation in Brazilian Holstein animals and Gir breeding bulls.

\section{MATERIAL AND METHODS}

\section{Animals}

For this study, 88 not closely related Holstein cows were sampled. Twenty-eight animals from the Animal Production Department of ESALQ/USP, 30 from Empresa Brasileira de Pesquisa Agropecuária - Centro de Pesquisa de Pecuária do Sudeste (Embrapa/CPPSE) and 30 animals from a private property in the São Roque municipality in the State of São Paulo. Eighty-eight Gir bulls were sampled among 126 participants in Embrapa's dairy cattle progeny tests at the National Dairy Cattle Research Center (Embrapa-CNPGL).

\section{Samples \\ Blood samples}

Whole blood $(500 \mu \mathrm{l})$ collected with EDTA from Holstein cattle, was lysed and washed three times with 1 $\mathrm{ml}$ of the lysing solution $(0.32 \mathrm{M}$ sucrose, $10 \mathrm{mM}$ Tris$\mathrm{HCl}, \mathrm{pH} 7.5,5 \mathrm{mM} \mathrm{MgCl}_{2}$ and $1 \%$ Triton X-100). The leukocyte pellet was then resuspended in $0.5 \mathrm{ml}$ of $50 \mathrm{mM}$ $\mathrm{KCl}, 10 \mathrm{mM}$ Tris-HCl, $\mathrm{pH} 8.3,1.5 \mathrm{mM} \mathrm{MgCl}_{2}, 1 \%$ Triton $\mathrm{X}-100$ and $60 \mathrm{ng} / \mu \mathrm{l}$ proteinase $\mathrm{K}$. The solution was incubated at $50^{\circ} \mathrm{C}$ for $1 \mathrm{~h}$, and subsequently at $95^{\circ} \mathrm{C}$ for $15 \mathrm{~min}$, causing proteinase $\mathrm{K}$ to be heat inactivated. DNA was stored at $-20^{\circ} \mathrm{C}$ until use.

\section{Semen samples}

Approximately $0.5 \mathrm{ml}$ of Gir cattle semen was centrifuged $(10,000 \mathrm{~g}, 10 \mathrm{~min})$ and washed four times with 1 $\mathrm{ml}$ PBS. The final pellet was resuspended in $100 \mu \mathrm{l}$ PBS and $400 \mu \mathrm{l}$ of lysing solution ( $2 \% \beta$-mercaptoethanol, 10 $\mathrm{mM}$ Tris-HCl, $\mathrm{pH}$ 8.0, $100 \mathrm{mM} \mathrm{NaCl}, 10$ mM EDTA, $\mathrm{pH}$ 8.0 , and $0.5 \%$ SDS). After incubating semen at $50^{\circ} \mathrm{C}$ for 30 min, $200 \mathrm{ng} / \mu \mathrm{l}$ proteinase $\mathrm{K}$ was added and the semen incubated at $52^{\circ} \mathrm{C}$ for $16 \mathrm{~h}$. Following this treatment, the sample was heated to $95^{\circ} \mathrm{C}$ for $15 \mathrm{~min}$ to inactivate proteinase $\mathrm{K}$. DNA was stored at $-20^{\circ} \mathrm{C}$ until use.

\section{PCR assay}

Amplification reactions of the DNA samples extracted from the blood were prepared in a final volume of $25 \mu \mathrm{l}$ containing: PCR buffer (20 mM Tris-HCl, pH 8.4, and 50
$\mathrm{mM} \mathrm{KCl}), 0.2 \mathrm{mM}$ dNTPs, 0.5 units Taq DNA polymerase, $1.5 \mathrm{mM} \mathrm{MgCl} 2,200 \mathrm{nM}$ each, of forward primer, 5'CCCTGCCAGTCCAGCTGGACACC3', reverse primer, 5'CCACGCCCATCATTCTGGGGCAG3' and $100 \mathrm{ng}$ of genomic DNA. Amplification was performed in 35 cycles of $15 \mathrm{~s}$ at $94^{\circ} \mathrm{C}$ and $20 \mathrm{~s}$ at $69^{\circ} \mathrm{C}$. Aliquots of the amplified products $(10 \mu \mathrm{l})$ were digested separately with four units of restriction enzymes TaqI and HaeIII, followed by incubation for $1.5 \mathrm{~h}$ at $65^{\circ} \mathrm{C}$ or $37^{\circ} \mathrm{C}$, respectively. Digested products were analyzed in $4 \%$ agarose gel and stained with ethidium bromide. DNA samples extracted from semen were amplified in a similar way to those extracted from blood; however, the PCR program included an initial denaturation of $3 \mathrm{~min}$ at $94^{\circ} \mathrm{C}$, followed by 35 cycles of $30 \mathrm{~s}$ at $94^{\circ} \mathrm{C}, 40 \mathrm{~s}$ at $65^{\circ} \mathrm{C}$ and 40 seconds at $72^{\circ} \mathrm{C}$ and a final extension of $5 \mathrm{~min}$ at $72^{\circ} \mathrm{C}$. The amplified product was precipitated to concentrate the DNA for digestion. The pellet was resuspended in $10 \mu \mathrm{l}$ MilliQ $\mathrm{H}_{2} \mathrm{O}$, followed by digestion with four units of the restriction enzyme TaqI for $3 \mathrm{~h}$ at $65^{\circ} \mathrm{C}$. The digested product was analyzed in a $3 \%$ agarose gel and stained with ethidium bromide.

\section{Allelic frequency estimate}

The gene frequency of the CD18 locus was calculated based on the Hardy-Weinberg law as follows:

$$
p=\frac{2(A A)+(A a)}{2 N} \quad q=1-p
$$

where $\mathrm{p}=$ normal allele frequency, $\mathrm{q}=$ mutant allele frequency, $\mathrm{N}=$ total number of animals tested, $\mathrm{AA}=$ number of BLAD-free cattle, and $\mathrm{Aa}=$ number of BLAD carriers.

The estimate of the occurrence of BLAD-affected animals was based on the genotypic frequency of BLAD carriers.

\section{RESULTS AND DISCUSSION}

The primers used were designed to amplify a DNA fragment of $58 \mathrm{bp}$. The restriction enzyme TaqI digested the PCR product into two fragments of 26 and $32 \mathrm{bp}$ in normal homozygote animals (Figure 1, all lanes, except 5, 7, 18 and 22, and Figure 2, lanes 1, 2, 3, 4 and 5). Heterozygote animals gave three fragments of 58,26 and $32 \mathrm{bp}$ (Figure 1, lanes 5, 7, 18 and 22).

In order to confirm the occurrence of the CD18 mutation, samples were digested with the HaeIII enzyme. This enzyme digests the PCR product into two fragments of 9 and $49 \mathrm{bp}$ in normal homozygote individuals and into three fragments of 9,19 and $30 \mathrm{bp}$ in affected animals. Heterozygote animals had four fragments of 9, 19,30 and $49 \mathrm{bp}$.

Analysis of the Holstein breed revealed that of the 88 Holstein cows genotyped, 83 were normal homozygotes and five were heterozygotes for the disease. The frequency of the BLAD mutant allele and the BLAD-carrier preva- 

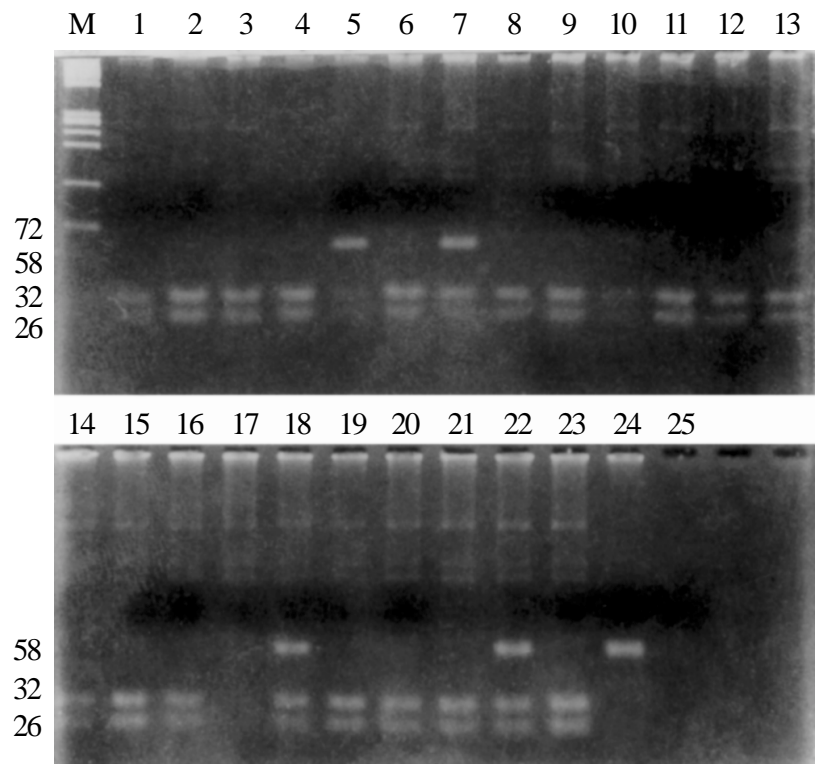

Figure 1 - Agarose gel electrophoresis of amplified DNA from BLAD-free and BLAD-carrier cows following restriction digestion with TaqI. Lanes 5, 7, 18 and 22 correspond to BLAD-carrier animals; lane 24 corresponds to undigested PCR-product and the remainding lanes correspond to DNA from BLAD-free cows.

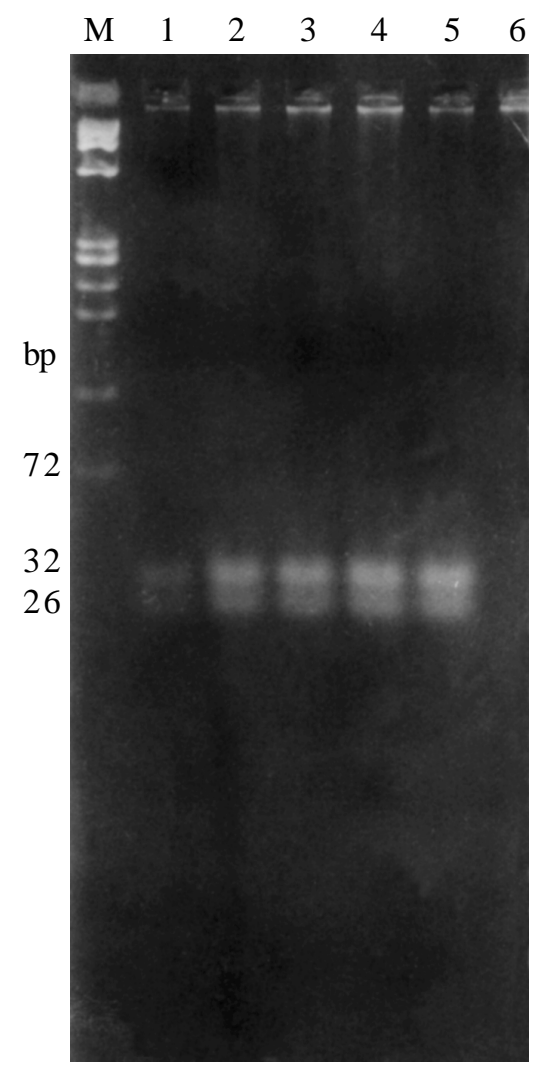

Figure 2 - Agarose gel electrophoresis of amplified DNA from Gir bulls following restriction digestion with TaqI. All animals were identified as normal homozygotes, i.e, BLAD-free animals. lence in Brazilian Holstein cows were 2.8 and $5.7 \%$, respectively. Of the Gir bulls tested, all were homozygous for the normal allele. We used cows in this test because the Holstein bulls that are used in artificial insemination are usually imported and are currently tested for BLAD.

The frequency of the heterozygote for the CD18 gene was similar to that found by Shuster et al. (1992) in American Holsteins, in which the observed heterozygote frequency was approximately $14.1 \%$ for bulls and $5.8 \%$ for cows. Holstein herds have been genotyped for this mutation in several countries. Frequencies are $3.5 \%$ in Argentinean Holstein cows (Poli et al., 1996), 13.4\% in Danish Holstein-Friesian cattle (Jorgensen et al., 1993) and 8.1\% in Japanese Holstein animals (Nagahata et al., 1997), indicating that this mutation is prevalent among Holstein cattle throughout the world.

We found that the genetic mutation responsible for BLAD in Holstein cattle was absent in all the Gir bulls analyzed from the Embrapa's dairy cattle progeny test. This result could be explained by two factors: either the CD18 gene mutation does not exist in Gir cattle or the frequency of this allele is extremely small and the size of the sample was not large enough for detection. New studies analyzing calves with characteristic BLAD symptoms could be conducted in order to further verify if this mutation occurs in Gir. In Holsteins, however, the incidence of the mutation was similar to that observed in herds in North America. Since BLAD is an economically important disease, Brazilian dairy farmers should avoid the use of semen from carrier bulls. This would prevent the introduction of the BLAD mutation in the Gir breed and the death of Holstein calves from BLAD.

\section{ACKNOWLEDGMENTS}

Research supported by grants from $\mathrm{CNPq}$ (Conselho Nacional de Desenvolvimento Científico e Tecnológico) and FAPESP (Fundação de Amparo à Pesquisa do Estado de São Paulo). Publication supported by FAPESP.

\section{RESUMO}

Oitenta e oito vacas da raça Holandesa e 88 touros da raça Gir foram genotipados através da PCR para o gene CD18 da deficiência de adesão de leucócitos em bovinos (BLAD). As frequiências do alelo mutante BLAD e de vacas heterozigotas da raça Holandesa foram 2,8 e 5,7\%, respectivamente. Por outro lado, todos animais Gir foram identificados como homozigotos normais, ou seja, nenhum alelo mutante BLAD foi encontrado. Estes resultados sugerem que a mutação no gene CD18 é prevalente em bovinos brasileiros da raça Holandesa e ausente ou presente numa freqüência muito baixa em animais Gir.

\section{REFERENCES}

Garcia, J.F., Gurgel, A.S.A., Visintin, J.A., Lunge, V.R. and Hoetzel, I. (1996). Use of DNA markers for genomic diagnosis of domestical ani- 
mals: 1. Detection of point mutation causing bovine leukocyte adhesion deficiency (BLAD) in Brazilian Holstein cattle. Braz. J. Vet. Res. Anim. Sci. 33: 133-135.

Gerardi, A.S. (1996). Bovine leukocyte adhesion deficiency: a review of a modern disease and its implications. Res. Vet. Sci. 61: 183-186.

Jorgensen, C.B., Agerholm, J.S., Pedersen, J. and Thomsen, P.D. (1993). Bovine leukocyte adhesion deficiency in Danish Holstein-Friesian cattle. I. PCR screening and allele frequency estimation. Acta Vet. Scand. 34: 231-236.

Kehrli Jr., M.E., Schmalstiey, F.C., Anderson, D.C., Vandermaaten, M.J., Hughes, B.J., Ackermann, M.R., Wilhelmsen, C.L., Brawn, G.B., Stevens, M.G. and Whetstone, C.A. (1990). Molecular definition of the bovine granulocytopathy syndrome: Identification of deficiency of the Mac-1 (CD11b/CD18) glycoprotein. Am. J. Vet. Res. 51: 1826-1836.

Kehrli Jr., M.E., Ackermann, M.R., Shuster, D.E., Gilbert, R.O. and Ryncarz, R.E. (1994). Bovine leukocyte adhesion deficiency. Proceedings of the 5th World Congress on Genetics Applied to Livestock Production, University of Guelph, Guelph, Ontario, Canada, Vol. 21.

Kishimoto, K.K., Hollander, N., Roberts, T.M., Anderson, D.C. and Springer, T.A. (1987). Heterogeneous mutations in the $\beta$ subunit common to the LFA-1, Mac-1, and p150,95 glycoproteins cause leukocyte adhesion deficiency. Cell 50: 193-202.

Martinez, M.L., Verneque, R.S. and Teodoro, R.L. (1998). Informativo Gir leiteiro. No. 1, Maio. EMBRAPA Gado de Leite, Juiz de Fora, MG.
Nagahata, H., Nochi, H., Tamoto, K., Taniyama, H., Noda, H., Morita, M., Kanamaki, M. and Kociba, G.J. (1993). Bovine leukocyte adhesion deficiency in Holstein cattle. Can. J. Vet. Res. 57: 255-261.

Nagahata, H., Miura, T., Tagaki, K., Ohtake, M., Noda, H., Yasuda, T. and Nioka, K. (1997). Prevalence and allele frequency estimation of bovine leukocyte adhesion deficiency (BLAD) in Holstein-Friesian cattle in Japan. J. Vet. Med. Sci. 59: 233-238.

Poli, M.A., Dewey, R., Semorile, L., Lozano, M.E., Albarino, C.G., Romanowski, V. and Grau, O. (1996). PCR screening for carriers of bovine leukocyte adhesion deficiency (BLAD) and uridine monophosphate synthase (DUMPS) in Argentine Holstein cattle. Zentralbl Veterinaermed A 43: 163-168.

Shuster, D.E., Kehrli Jr., M.E., Ackermann, M.R. and Gilbert, R.O. (1992). Identification and prevalence of a genetic defect that causes leukocyte adhesion deficiency in Holstein cattle. Proc. Natl. Acad. Sci. USA 89: 9225-9229.

Springer, J.A. (1990). Adhesion reception of the immune system. Nature 346: 425-434.

Tajima, M., Irie, M., Kirisawa, R., Hagiwara, K., Kurosawa, T. and Takahashi, K. (1993). The detection of a mutation of CD18 gene in bovine leukocyte adhesion deficiency (BLAD). J. Vet. Med. Sci 55: 145-146.

(Received December 20, 1999) 